\title{
Histopathology of aseptic necrosis of the femoral head in sickle cell disease
}

\author{
Martin Mukisi-Mukaza • Anne Gomez-Brouchet • \\ Monique Donkerwolcke • Maurice Hinsenkamp • \\ Franz Burny
}

Received: 17 August 2010 /Revised: 20 August 2010 /Accepted: 24 August 2010 /Published online: 10 September 2010

(C) Springer-Verlag 2010

\begin{abstract}
This study compares the histopathology of bone biopsies from patients suffering from sickle cell anaemia (homozygote SS) to heterozygote patients (SA) and homozygotes with aseptic osteonecrosis (AA). The sensitivity to bacterial infection of sickle cell patients raises the question of the aetiology of sepsis in the onset of the necrosis. To our knowledge this study is the first to analyse the histopathology of osteonecrosis of the femoral head, at its early stages, in sickle cell anaemia. At the University Hospital of Pointe-à-Pitre, from 1994 to 2007, 38 bone biopsies were obtained from adult patients with avascular necrosis of the femoral head at the time of a core decompression procedure (SS, SC: 27; AS: 5; AA: 6). The histology of the biopsies confirmed the necrosis; all bacteriological cultures were negative. Patients displaying one $\mathrm{S}$ gene (SS, SC, AS) compared to homozygote subjects (AA) showed a significant increase of a nonspecific inflammatory granulomatosis $(p=0.003)$. No relationship
\end{abstract}

M. Mukisi-Mukaza

Service d'Orthopédie Traumatologie, CHU de Pointe-à-Pitre, Guadeloupe, France

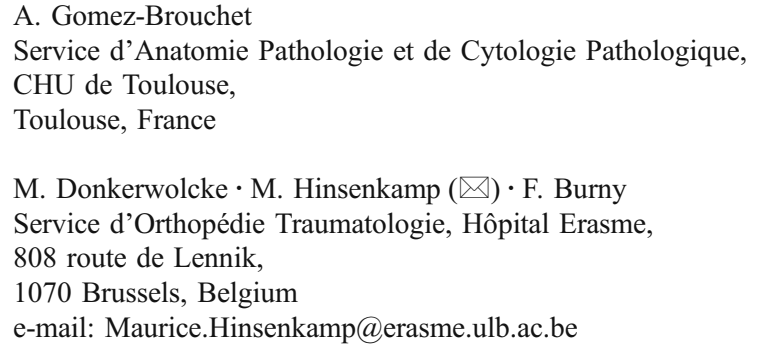

was observed between the radiological stages and the histology whatever the genotype $(p=0.1)$. Inflammatory histopathology without sepsis or advanced alteration characterises the early stages of sickle cell necrosis. This inflammatory process is absent in idiopathic avascular necrosis.

\section{Introduction}

Idiopathic necrosis consists of death of bone in a greater or lesser part of the femoral head without osteomyelitis, significant trauma or tumour. When the aetiology is known, the necrosis is said to be secondary, as in sickle cell hip necrosis $[1,7,12,26]$.

Hungerford [18] proposed an early diagnosis of aseptic osteonecrosis based on the measurement of the intramedullary pressure (IMP) and the histology of the core biopsy. Ficat and Utheza [11] studied bone biopsies to improve the knowledge of the pathological process and the accuracy of the diagnosis. The histopathological images of idiopathic or secondary necrosis of the femoral head have been described by Arlet and Durroux [2], Arlet et al. [3], Noël et al. [23] and Hauzeur et al. [15]. These studies are only descriptive, without aiming to relate to the radiological classification proposed by Arlet and Durroux [2]. Up to now, no study of the early stage of sickle cell osteonecrosis of the femoral head, before sequestration, has been available. As patients suffering from sickle cell anaemia are sensitive to infection, it is important to know if sepsis initiated the pathological process as in diaphyseal necrosis $[5,9,10]$. 


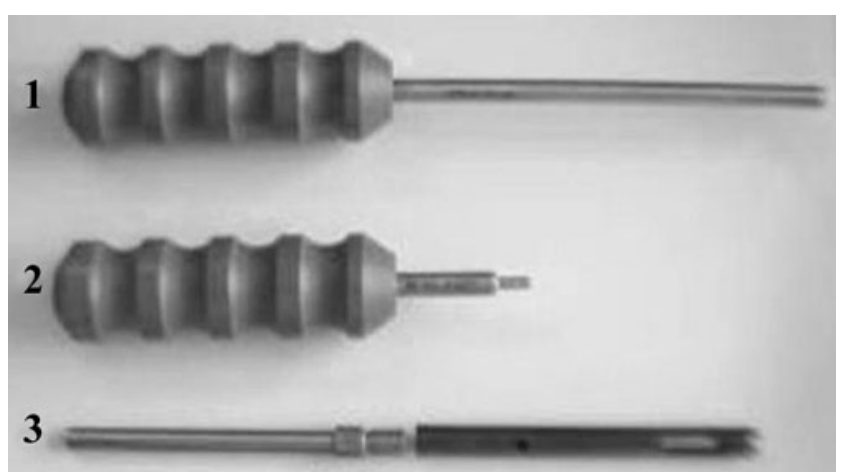

Fig. 1 Specific stainless steel trephine graft extractor (1), release tool for extension trephine (2), trephine $8 \mathrm{~mm}$ diameter and $100 \mathrm{~mm}$ length and extension trephine of $100 \mathrm{~mm} \mathrm{(3)}$

We therefore compared core biopsies from patients with sickle cell anaemia (SS) or heterozygotes (SA) with patients free from sickle cell gene (AA), but with necrosis. Our objectives were to find:

- A possible relationship between the radiological image and the histopathology of the sickle cell patients with genotype SS or SA and the non-sickle cell patients (AA)

- If bacterial infection is involved in the onset of the necrotic lesion

\section{Materials and methods}

\section{Patients}

Between 1994 and 2007, at the University Hospital of Pointe-à-Pitre, 38 core biopsies were made in patients between 16 and 55 years old: 27 in sickle cell anaemia patients (SS, SC), five in heterozygotes (AS) and six in patients without sickle trait (AA). The sampling was obtained during a core decompression treatment [22].
Sampling procedure

Neither the Ficat trephine [11] nor the Mazabraud trocar [20] was used due to the hardness of the cortex in sickle cell disease. The percutaneous core biopsy was made under general or regional anaesthesia (2-4 cm incision), as described by Ficat and Utheza [11], in a supine position on an orthopaedic table, with an image intensifier allowing anteroposterior (AP) and lateral views of the hip. The percutaneous drilling was done using an $8 \mathrm{~mm}$ stainless steel trephine (Carpenter 455) devised in the department (Fig. 1), electrically powered through the lateral cortex, up to the subchondral bone without damaging the cartilage, to harvest a $6 \mathrm{~mm}$ diameter bone fragment (a bilateral procedure is possible during the same operation). We recommend 24-hour drainage, early mobilisation and respiratory physical therapy, anti-coagulotherapy and limited weight-bearing period of six weeks.

\section{Fixation techniques}

The samples obtained were sent directly to the Department of Anatomo-pathology. A first sample was obtained from the biopsy and stained with May-Grünwald-Giemsa (MGG, for semi-quantitative evaluation of leucocytes) [4]. The cylindrical biopsies were kept in a $10 \%$ formol buffer solution for 12 hours and decalcified in RDO (Eurobio) for one to four hours. They were embedded in paraffin after dehydration (Shandon Pathcentre, for 15 hours). Sections measuring $4 \mu \mathrm{m}$ were stained with haematoxylin and eosin (H\&E) and Masson trichrome.

\section{Histological examination}

The analysis of the sections at the University Hospital of Pointe-à-Pitre were made under light microscopy for quantitative evaluation of the bone structure. The slides were also examined in the Department of Histology, Toulouse, for the description of the sickle cell lesions. The histological results were classified by the method of

Table 1 Histological classification [2]

\begin{tabular}{ll}
\hline Type & Description \\
\hline Type 1 & Nonspecific marrow plasmostasis with few foam cells and focal area of granular eosinophilic necrosis; no bone alteration \\
Type 2 & Marrow necrosis: medullary spaces are replaced by granular, eosinophilic necrosis, oedema, haemorrhages, fibrous reticulosis, \\
& haematopoietic necrosis, progressive extension of focal lesions \\
Type 3 & Type $2+$ trabecular necrosis $(50 \%$ death of osteocytes) \\
Type 4 & Type $3+$ fibrosis and creeping substitution \\
\hline
\end{tabular}


Table 2 Radiological classification [3] modified by ARCO [14]

\begin{tabular}{|c|c|}
\hline Stage & Description \\
\hline Stage I & Absence of radiological alteration, positive scintigraphy or MRI \\
\hline Stage II & $\begin{array}{l}\text { Early radiological signs (X-ray, CT scan): osteosclerosis, focal heterogeneity of trabecular bone, joint space and sphericity of the } \\
\text { femoral head preserved }\end{array}$ \\
\hline Stage III & Alteration of the trabecular bone, discontinuity of the subchondral bone (uni- or bipolar breakage with or without impaction) \\
\hline Stage IV & Cartilaginous alteration (thinning, osteophytes, osteoarthritis) \\
\hline
\end{tabular}

Arlet and Durroux [2] (Table 1) and compared to those obtained with up-to-date technologies [computed tomography (CT) scan, magnetic resonance imaging (MRI)] [12].

A positive histology for idiopathic aseptic necrosis is characterised by trabecular necrosis (more than 50\% of empty osteocytic lacunae) and necrotic haematopoietic marrow in the absence of specific lesions of inflammation, sepsis or tumour cells $[11,13,15,23]$.

\section{Radiology}

The Arlet radiological classification of osteonecrosis was used upgraded by the new imaging techniques [12, 26]. Four stages are described (Table 2).

\section{Results}

Macroscopic description

The cores sampled with the trephine appeared as bone cylinders of $6 \mathrm{~mm}$ diameter and $6 \mathrm{~cm}$ in length. They were macroscopically composed of two parts (Fig. 2):

- A distal segment, dense whitish scattered red colouration (a), the necrotic part of the head

- A proximal segment, alive and red (b), the more or less normal bone from the cervical area

\section{Histology}

Histology showed cancellous bone well organised and repairable trabeculae in the proximal part of the biopsy that corresponded to the cephalic bone necrosis (Fig. 3a). The distal part consisted of thin trabeculae less organised, frail and distorted by the reaming (Fig. 3b). All samples showed histological characteristics of necrosis. The most frequent patterns were types 2 and 4 and type 2 associated with 4 (Table 3, Figs. 4 and 5).

Types 1 and 3 were never observed and type 4 lesions were present in all patients. In SC patients there were 35\% type 4 and $65 \%$ type $2-4$. For AA patients types 2 and 4 each represent $50 \%$ of the cases; there was no type $2-4$ association, a type only observed in SC patients ( $p=0.006$; Table 3$)$.

\section{Bacteriology}

Bacteriological cultures of the core biopsies were all negative. The MGG staining did not show any leucocytes.

Genotype and inflammation

The genotypes with at least one $\mathrm{S}$ gene (SS, SC, AS) and the AA group showed an inflammatory pattern (presence of lymphocytes) significantly increased in sickle cell patients (SS, SC) or SA heterozygotes, when compared to the images of osteonecrosis observed in AA patients $(p=0.0003$; Table 4). There was no difference between genotypes SS and SC ( $p=0.09$; Table 4$)$.

Fig. 2 Core biopsy, $6 \mathrm{~mm}$ diameter. a Distal segment, dense whitish scattered red colouration of the necrotic part of the head. b Proximal segment, alive and red

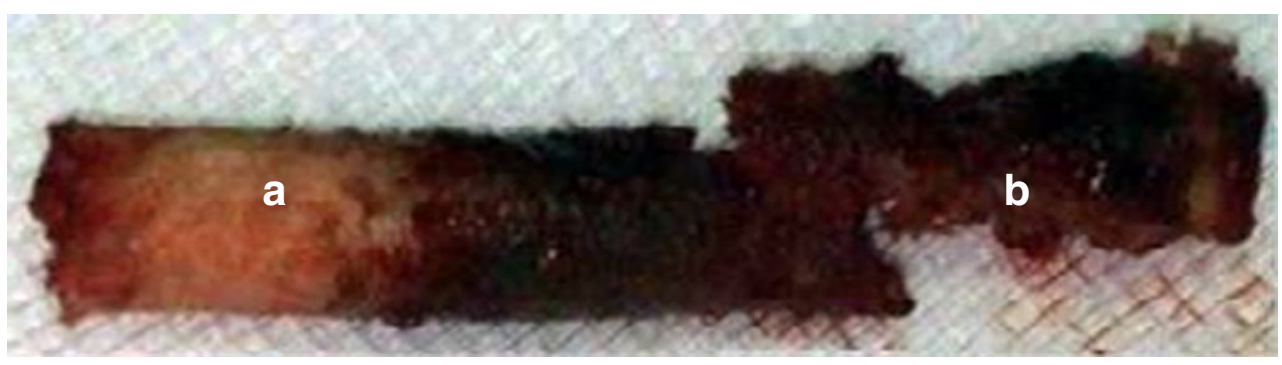




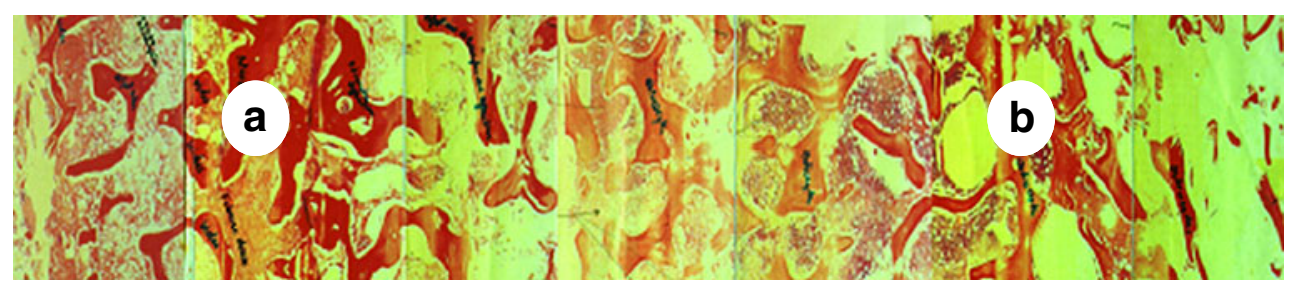

Fig. 3 Histological section of bone cylinder, well organised and repairable bone trabeculae in the proximal part (a); thin, irregular and disrupted trabeculae in the distal part (b)

Radiology and histology staging

No relationship could be established between radiology and histology staging whatever genotype ( $p=0.82$; Table 5).

\section{Discussion}

Bacterial contamination

Septic osteoarticular complications are frequent in sickle cell patients $[9,10,27]$. The negative bacteriological sampling confirms the vascular aetiology by ischaemic occlusion of the sinusoids by the sickle cells. Septic complication remains the exception in epiphyseal lesions $[9,10,17]$.

\section{Genotype and histology}

Sickle cell osteonecrosis of the femoral head characterised by cellular death after chronic ischaemia explains the presence of lesion type 2 (associated with type 4 ) or type 4 in groups (SS, SC and AC, Table 3). The clinical manifestations of vascular occlusion, ischaemia and severity of SS genotype explain the constant presence of type 4 histological lesions in this group and the presence of type 2 (associated with type 4) in the SC group [5, 25]; we observed that bone lesions are present in heterozygotes AS (type 4 lesions). The histopathology of sickle cell osteonecrosis of the femoral head is, in addition to medullary necrosis (type 2) and bone necrosis, always

Table 3 Genotypes and histological images

\begin{tabular}{lllll}
\hline Genotypes & Type 2 & Type 4 & Type 2-4 & Total \\
\hline SS & - & $13(100 \%)$ & - & 13 \\
SC & - & $5(35 \%)$ & $9(65 \%)$ & 14 \\
AS & - & $5(100 \%)$ & - & 5 \\
AA & $3(50 \%)$ & $3(50 \%)$ & - & 6 \\
Total & 3 & 26 & 9 & 38 \\
\hline
\end{tabular}

associated with osteogenesis (type 4) as confirmed by macroscopic images [17]. Type 2 lesions alone are only present in the AA group and not in sickle cell trait (SS, SC and AS), an observation already reported by Arlet et al. [3] (Table 3).

Genotype and inflammatory reaction

The histological definition of aseptic necrosis excludes inflammatory manifestations [3]. Inflammatory reactions appear to characterise sickle cell disease in several anatomical locations [21, 24]. They are always present in umbilical cord and placental veins (terminal vascularisation) in sickle cell births [6]. In contrast to idiopathic necrosis, the histopathology of sickle cell necrosis shows a nonspecific inflammation, revealed by the presence of lymphocytes.

Radiological and histological stages

All sections showed necrotic images, but we never observed type 1 lesions (isolated medullary necrosis). This can be explained by late biopsy, seldom made at the

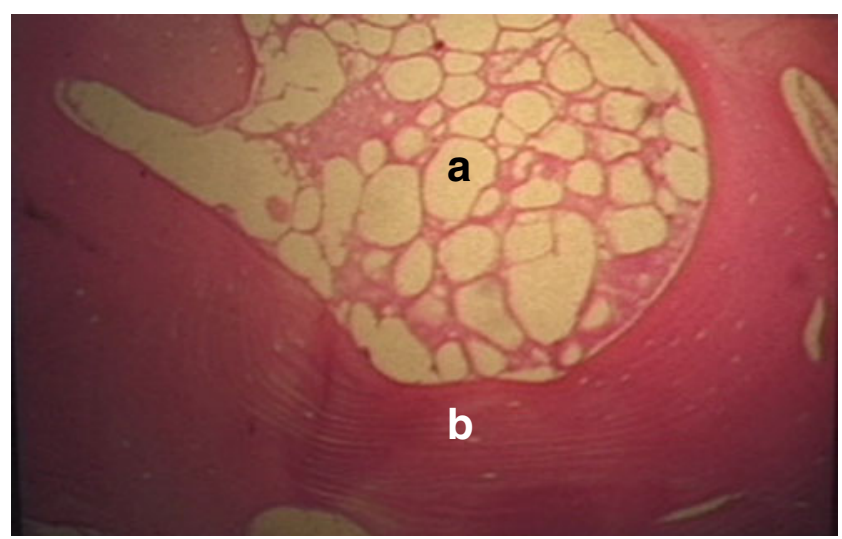

Fig. 4 Fat marrow necrosis (type 2) associated with bone necrosis (H\&E staining, $\times 10)$. a Fat marrow necrosis: eosinophilic reticulated necrosis. b Trabecular necrosis (empty lacunae) and new bone apposition 


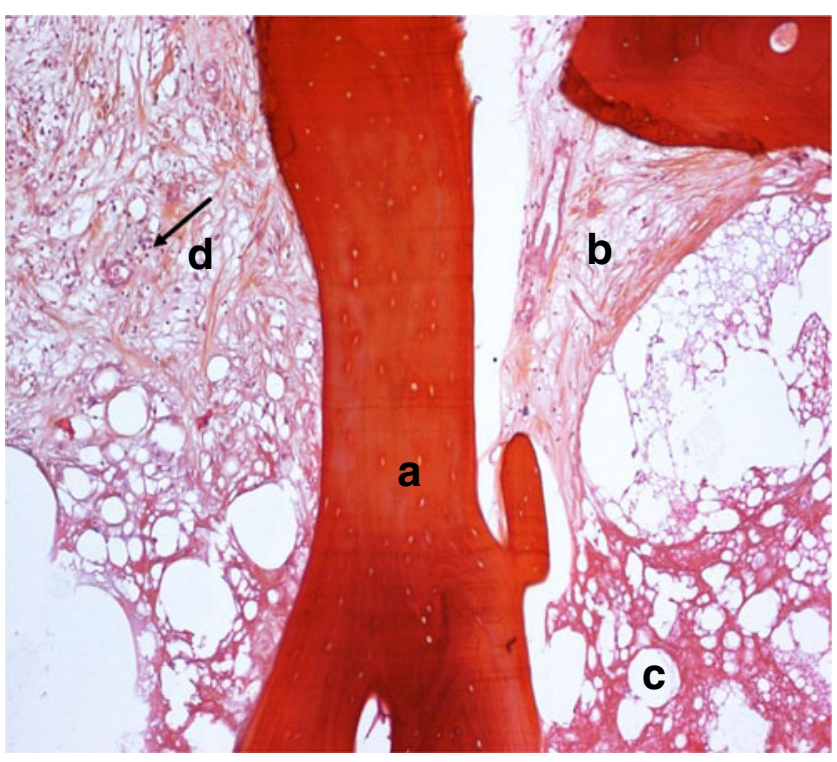

Fig. 5 Sickle cell osteonecrosis associated, type 2-4: eosinophilic reticulated necrosis of the fat marrow (type 2) with inflammation, fibrosis and bone apposition (type 4): Bone necrosis $(A)$, medullary necrosis $(B)$, fibrosis $(C)$, lymphocytes (black arrow) $(D)$

initial stage of the osteonecrosis (Table 5) and by the association of lesions from different stages due to chronic ischaemia characterising sickle cell disease. Several weeks are needed before the observation of cell necrosis $[2,23]$.

The radiological classification of Arlet et al. is not related to histology because of the overlapping of diffuse necrotic lesions at different stages. As in aseptic necrosis there is no correspondence between histopathology and radiological stage [8]. More obvious in sickle cell osteonecrosis, the osteocytes disappear from bone lacunae due to the chronic ischaemia without alteration of the radiological image (Table 5). In stage 1 standard radiology remains silent. Only the medullary modifications (plasmostasis, adipocyte alteration) are visible on MRI [14-16]. On the first radiological images, new bone appositions appear on empty trabeculae and correspond to bone sclerosis [19].

Table 4 Genotypes and inflammatory manifestation

\begin{tabular}{llll}
\hline Genotypes & Present & Absent & Total \\
\hline SS & $13(100 \%)$ & - & 13 \\
SC & $11(79 \%)$ & $3(21 \%)$ & 14 \\
AS & $5(100 \%)$ & - & 5 \\
AA & $1(16.7 \%)$ & $5(83.3 \%)$ & 6 \\
Total & 30 & 8 & 38 \\
\hline
\end{tabular}

Table 5 Radiological stages and histological images

\begin{tabular}{|c|c|c|c|c|c|c|}
\hline \multicolumn{3}{|c|}{ Radiological stage } & \multicolumn{4}{|c|}{ Histology } \\
\hline & Type 1 & Type 2 & Type 3 & Type 4 & Type 3-4 & Tota \\
\hline Stage 1 & - & - & - & $3(75 \%)$ & $1(25 \%)$ & 4 \\
\hline Stage 2 & - & - & - & $13(76.5 \%)$ & $4(23.5 \%)$ & 17 \\
\hline Stage 3 & - & $2(11.8 \%)$ & - & $11(64.7 \%)$ & $4(23.5 \%)$ & 17 \\
\hline Total & - & 2 & - & 27 & 9 & 38 \\
\hline
\end{tabular}

\section{Conclusion}

We stress the original aspect and the specific lesions of this study of the histopathology of sickle cell osteonecrosis of the femoral head. The images are characterised by extended and diffuse bone marrow necrosis of the eosinophilic type, associated with granulation tissue, trabecular necrosis, fibrosis and new bone apposition on ischaemic trabeculae without relation to radiological stages. Medullary alterations are constant (haematopoietic and fat marrow necrosis associated with unusual inflammatory signs). Thick bone trabeculae attest to the permanent bone formation by apposition of living bone on necrotic matrix. In contrast to idiopathic avascular necrosis, the sickle cell necroses of the head are characterised by an inflammatory reaction without any bacterial contamination and advanced lesions at the earliest stages.

Whatever the genotype, there is no relationship between radiological stage and histology due to the overlapping and the extension of necrotic lesions. From this study, we may conclude that sickle cell osteonecrosis is a specific entity characterised microscopically by diffused necrotic lesions of bone trabeculae and marrow, associated with an inflammatory process and new bone formation. This new apposition is responsible for osteosclerosis leading to a homogeneous increase of density of the head.

These images are the consequence of a chronic ischaemia evolving at the same time as medullary osteoblastic activity. Bone repair is permanent by creeping substitution. No evidence of hyperactive resorption preceding osteogenesis can be observed which attests to the efficacy of the osteoblastic activity.

Acknowledgements Thanks to A. Marrell, M.D., Department of Anatomic Pathology of CHU de Pointe-à-Pitre for her help.

Conflicts of interest There are no conflicts of interest of any of the authors. 


\section{References}

1. Akinyoola AL, Adediran IA, Asaleye CM, Bolarinwa AR (2009) Risk factors for osteonecrosis of the femoral head in patients with sickle cell disease. Int Orthop 33:923-926

2. Arlet J, Durroux R (1973) Diagnostic histologique précoce de l'ostéonécrose aseptique de la tête fémorale par le forage-biopsie. In: "La circulation osseuse, compte rendu du 1er Symposium International sur la circulation osseuse". INSERM Ed., Paris, 293302

3. Arlet J, Durroux R, Fauchier C, Thiechart M (1984) Histopathology of nontraumatic necrosis of the femoral head: topographic and evolutive aspects. In: Arlet J, Ficat RP, Hungerford DS (eds) Bone circulation. Williams \& Wilkins, Baltimore, pp 296-305

4. Audouin J, Delacrétaz F, Diebold J, Dumont J, Le Tourneau A, Meugé-Moraw C (2004) Biopsie médullaire osseuse en pratique quotidienne, Le Pathologiste, Collection dirigée par J. Diebold. Elsevier, Paris, 352P

5. Cabannes R, Sangare A, Garnier E, Kiple-Faget P, Abissey S (1981) Physiopathologie de la drépanocytose. Med Afr Noire 26:277-284

6. Decastel M, Leborgne-Samuel Y, Alexandre L, Mérault G, Berchel C (1999) Morphological features of the human umbilical vein in normal, sickle cell trait, and sickle cell disease pregnancies. Hum Pathol 30:13-20

7. de Sèze S, Welfling J, Lequesne M (1960) L'ostéonécrose primitive de la tête fémorale chez l'adulte. Rev Rhum Mal Osteoartic 27:117-127

8. Durroux R, Arlet J (1971) Critiques de signes histologiques de nécrose osseuse. Rhumatologie 23:309-311

9. Ebong WW (1980) The treatment of severely ill patients with sickle cell anemia and associated septic arthritis. Clin Orthop Relat Res 149:145-152

10. Ebong WW, Kolawole TM (1986) Aseptic necrosis of the femoral head in sickle-cell disease. Br J Rheumatol 25:34-39

11. Ficat P, Utheza G (1968) Le forage-biopsie de la hanche. Rev Med Toulouse 9:223-230

12. Gardeniers JWM (1993) Report of the committee of staging and nomenclature. ARCO News Letter 5:79-82

13. Hauzeur JP, Orloff S, Taverne-Verbanck J, Pasteels JL (1986) Diagnosis of aseptic osteonecrosis of the femoral head by percutaneous transtrochanterian needle biopsy. Clin Rheumatol 5:346-348

14. Hauzeur JP, Pasteels JL, Schoutens A, Hinsenkamp M, Appelboom T, Chorchard I, Perlmutter N (1989) The diagnostic value of magnetic resonance imaging in non-traumatic osteonecrosis in the femoral head. J Bone Joint Surg Am 71:641-649
15. Hauzeur JP, Sintzoff J, Appelboom T, De Maertelaer V, Bentin J, Pasteels JL (1992) Relationship between magnetic resonance imaging and histologic findings by bone biopsy in nontraumatic osteonecrosis of the femoral head. J Rheumatol 19:385-392

16. Hernigou Ph, Voisin MC, Despres E, Goutalier D (1984) Confrontation de l'imagerie par résonance magnétique nucléaire et de l'histologie dans les nécroses des têtes fémorales. Rev Rhum Mal Osteoartic 56:741-744

17. Hernigou P, Galacteros F, Bachir D, Goutallier D (1989) Histoire naturelle de la nécrose de la hanche dans la maladie drépanocytose. A propos de 104 cas. Rev Chir Orthop Reparatrice Appar Mot 75:542-557

18. Hungerford DS (1975) Early diagnosis of ischemic necrosis of the femoral head. Johns Hopkins Med J 137:270-275

19. Malghem J, Maldague B (1981) Aspects radiologiques des nécroses épiphysaires et implications pathogéniques. Acta Orthop Belg 47:200-224

20. Mazabraud A (1969) De la localisation polaire supérieure dans la nécrose de la tête fémorale. Presse Med 77:1979-1982

21. Monnet D, Edjeme NE, Ndri K, Hauthouot-Attoungbre ML, Ahibo H, Sangare A, Yapo AE (2002) La lipoprotéine (a), les protéines de la phase aiguë de l'inflammation au cours de la crise drépanocytaire homozygote. Ann Biol Clin (Paris) 60:101-103

22. Mukisi-Mukaza M, Manicom O, Alexis C, Bashoun K, Donkerwolcke M, Burny F (2009) Treatment of sickle cell disease's hip necrosis by core decompression: a prospective case-control study. Orthop Traumatol Surg Res 95:498-504

23. Noël H, Degels MA, Coutelier L (1981) Anatomie pathologique de la nécrose aseptique, idiopathique de la tête fémorale. Acta Orthop Belg 47:191-197

24. Pululu EDK (2006) Variations physiopathologiques de la leucocytose dans la morbi-mortalité chez l'enfant drépanocytaire. Mémoire de fin de spécialisation en pédiatrie, Faculté de Médecine, Université de Kinshasa, RDC, 81P http://www.

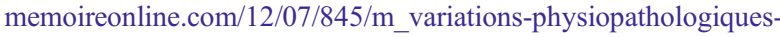
leucocytose-morbi-mortalite-enfant-drepanocytaire 14.html. Accessed 9 Jul 2009

25. Ratcliff RG, Wolf MD (1962) Avascular necrosis of the femoral head associated with sickle cell trait (AS hemoglobin). Ann Intern Med 57:299-304

26. Schmitt-Sody M, Kirchhoff C, Mayer W, Goebel M, Jansson V (2008) Avascular necrosis of the femoral head: inter-and intraobserver variations of Ficat and ARCO classifications. Int Orthop 32:283-287

27. Vandepitte JM, Renoirte AM, Gatti F (1966) Ostéomyélite à Salmonella typhi comme complication de l'anémie falciforme. Ann Soc Belg Med Trop 46:381-386 